\title{
Assessment of Domestic Wastewater Management Practices in the Communal District I of Maradi City, Niger Republic
}

\author{
Ousmane Laminou Manzo1*, Hassidou Saidou², Salamatou Abdourahamane Illiassou3, \\ Saoudé Tidjani Idrissa ${ }^{3}$ \\ ${ }^{1}$ Department of Agricultural Engineering and Water \& Forests, Faculty of Agronomy and Environmental \\ Sciences, Dan Dicko Dankoulodo University of Maradi, Maradi, Niger \\ ${ }^{2}$ Department of Chemistry, Faculty of Science and Technology, Dan Dicko Dankoulodo University of Maradi, \\ Maradi, Niger \\ ${ }^{3}$ Department of Biology, Faculty of Science and Technology, Dan Dicko Dankoulodo University of Maradi, \\ Maradi, Niger \\ Email:
}

Received 6 September 2015; accepted 17 October 2015; published 20 October 2015

Copyright (C) 2015 by authors and Scientific Research Publishing Inc.

This work is licensed under the Creative Commons Attribution International License (CC BY). http://creativecommons.org/licenses/by/4.0/

(c) (i) Open Access

\section{Abstract}

Wastewater treatment is a problem with much acuity in the city of Maradi in general, and particularly in the Communal District I of Maradi. It is for this reason that the present study was conducted which deals with wastewater sanitation. The main objective of this study conducted through a survey is to investigate in the domestic wastewater sanitation in the Communal District I of Maradi city. Specifically, the study aims to estimate the amount of wastewater produced by households and to analyze the sanitation system at household and at district levels. The wastewater management practices in this district were assessed through a descriptive cross sectional study in which a total of 129 households were selected by sample distribution technique in the district neighborhoods and studied using interviewer and administered questionnaires at communal and household levels. The results of the study showed that the amount of domestic wastewater generated is quite large, about $32.27 \mathrm{~m}^{3}$ per person per day, and this comes from several sources including showers, laundry, dishwashing and income generating activities. The results also revealed that the unhealthy state of the Communal District I of Maradi is related to the absence of a wastewater treatment system, the methods and practices used in its management, and the population is also largely responsible for this unhealthy state and not willing to participate to a sanitation project.

${ }^{*}$ Corresponding author.

How to cite this paper: Laminou Manzo, O., Saidou, H., Abdourahamane Illiassou, S. and Tidjani Idrissa, S. (2015) Assessment of Domestic Wastewater Management Practices in the Communal District I of Maradi City, Niger Republic. Journal of Geoscience and Environment Protection, 3, 57-65. http://dx.doi.org/10.4236/gep.2015.38006 
Keywords

Domestic Wastewater, Sanitation, Communal District I of Maradi, Management Practices

\section{Introduction}

African cities are generally over populated because of the exodus of rural populations in search for employment. In most of these cities, waste management and wastewater in particular is a major concern of the people. The wastewater is a by-product of utilized portable water (domestic wastewater) or industrial process water (industrial wastewater) [1]. Sanitation in these cities is usually dominated by the autonomous sanitation systems (about $60 \%$ - $95 \%$ of people) [2]. In Africa and Asia, it is estimated that $65 \%$ to $100 \%$ of homes, which have sewerage systems, are equipped with stand-alone installations that are not connected to a sewer system [3]. This is explained by the fact that the construction of drainage systems is very expensive for these countries.

Practically all the cities in the Niger have the same situation where the autonomous systems are not connected to a sewage network. The city of Maradi is not an exception. Indeed, it is experiencing an accelerated urbanization boom and rapid growth population. These two phenomena are the basis of the increased domestic water demand and consequently a significant increase in the volume of wastewater generated in various forms (excreta, toilet water, dishwashing and laundry, wastewater generated by the activities generating income).

The lack of a complete sewerage system in the different zonal areas makes that the wastewater produced is mostly discharged directly into the environment without any treatment. Indeed, the autonomous sanitation systems used (traditional latrines, septic tanks) generate effluents that are rich in fecal coliforms, helminths, viruses, protozoa, and in other various chemical and physical pollutants. The intrusion of these fecal wastes in aquifers or in water distribution system can be a source of contamination of various diarrheal diseases in communities.

Nevertheless, we note the existence of some culverts for the rainwater drainage in some zonal quarters, but used for the disposal of domestic wastewater. However, in areas where it exists, the malfunction of the system disables the evacuation of these waters, especially in densely populated areas. Urban safety is constantly threatened by stagnant sewage in the empty spaces on the floor, in the streets and drains.

Untreated sewage, lack of a proper environmental sanitation system (excreta management, water drainage) and poor hygiene contribute to a large extent to the deterioration of public health and degradation of the life frame of the populations of Maradi city.

The sanitation system of the city is not, for the people, a guarantee against the risk of disease and degradation of their surroundings because of his failure. Therefore, it is urgent to turn to integrated waste management approach to ensure sustainable sanitation in the city.

Thus, in view of the environmental and health interests of the sanitation sector and also its importance in the urban development process, this study aims to contribute to the improvement of the living in Maradi city, through the case study of Municipal District I of Maradi. The overall objective of this study is to contribute to sustainable domestic wastewater sanitation in the Communal District I of Maradi in order to improve the living conditions of populations.

\section{Materials and Methods}

\subsection{Presentation of the Communal District I of Maradi}

The population of the Municipal District I of Maradi is of about 94,122 inhabitants with 50.25\% of women [4]. This population is predominantly urban and consists of the following ethnic groups: Hausa (92\%), Fulani (4.6\%), Tuaregs $(1.4 \%)$ and others $2 \%$. The density of the population is of about 10 inhabitants per $\mathrm{km}^{2}$. The average size of a household is of about 7 people. This means that they are about 13,446 households in the Communal District I of Maradi.

The problems of housing and urban planning in the municipality still not taking into account the topography of the area (many high sloppy zones), the presence of bed of old Kori, and the pattern of urbanization, which is lacking for this district, in the habitats construction. In rainy season, the district face dwellings damage (houses collapse), and problems of drainage of rain water and even sewage. Misbehavior, carelessness of the population 
in compliance with the rules of hygiene and inadequate disposal of household waste materials are all problems that complicate the benefit of management and maintenance of safety in this municipal district I of Maradi.

\subsection{Observation Units}

A survey was conducted in the Communal district I of Maradi. It is carried out at two levels: communal level (1) and household one (2) and questionnaires were administrated to the population in order to collect sociodemographic variables which are related to the wastewater management and those related to environmental problems.

At the household level, the survey will allow assessing the state of the living environment in these settlements at this level through the different wastewater management modes and practices.

The assessment at the communal level, which constitutes the outside environment or the communal area, will analyze and appreciate the level of the unhealthy state of the neighborhood environment.

\subsection{Methods}

\section{- Sample distribution}

The survey was based on the questionnaire mode and carried out on a sample of the studied population. It has affected households. The results obtained are extrapolated to the entire communal district I territory. The sampling frame is a list of geographical units which correspond to geographical areas and the component units are households. The survey type selected is that of the sample survey in which data collection is made for only some of the units usually very small population. The sampling method chosen is simple probabilistic and random type. It is a method of selection in one step that can make inferences about the population, given the observations from the sample and ensures that every possible sample size $n$ has an equal chance of being selected [5] [6].

According to the 2011-2015 Social Development Plan the Urban Community of Maradi, the distribution of the population, and thus the households in neighborhoods is the following : Bouzou Dan Zambadi: 15.9\%; Mazadou Jika: 6\%; Nouveau carré: 19.1\%; Soura Alladey: 6.6\%; Soura Bildi: 19.8\%; Zaria I: 32.6\%.

According to the above percentages, the sample distribution of the study in the Communal District I is of about 129 households and is composed as follow: Bouzou Dan Zambadi: 20 households; Mazadou Jika: 8 households; Nouveau carré: 25 households; Soura Alladey: 8 households; Soura Bildi: 26 households; Zaria I: 42 households.

\section{- Survey questionnaire}

The questionnaire consisted of twenty six questions which are used in the survey. Questions are addressed and discussed with household head. The main topics of this survey include sociodemographic characteristics of households; wastewater production sources; wastewater management methods and practices; sanitation facilities (structures) used; wastewater disposal practices and; amount of water used for daily needs.

\section{- Interview}

An interview with officials in charge of hygiene and sanitation and those in charge of urban planning from the city of Maradi was conducted to analyze the sanitation system at municipal level. These interviews were also based on a questionnaire.

\subsection{Data Processing and Analysis}

The sociodemographic data are related to variables such as type of housing, household size, age, sex, education level and type of employment of household head, Analysis of these is to evaluate the share of households in the wastewater production. Also, the degree of involvement of the population in the environmental management is appreciated.

The analysis of data from variables such as wastewater disposal modes, sanitation structures and wastewater management practices of the population related data help to know the views of people on the state of environment unhealthiness and the possibility of an environmental participatory management.

The analysis of data related to hygiene and sanitation of the population environment, wastewater collection and; impacts of poor sanitation on people allow to assess the actual level of living environment degradation and to analyze the environmental impact caused by wastewater.

Data analysis was carried out in Excel and SPSS11.5 software. The statistical processing with Excel software has allowed drawing tables and charts. SPSS 11.5 software has used to describe data and to calculate descriptive 
statistical parameters, to analyze correlations of education level of household head and 1) wastewater production, 2) wastewater management modes and 3) practices using Pearson correlation analysis.

One-way analysis of variance (ANOVA) was performed to test the significance of differences in education level of household head and 1) wastewater production, 2) wastewater management modes and 3) practices. The Tukey-Kramer Multiple Comparisons Test was used to compare those parameters and education level.

\section{Results}

\subsection{Sociodemographic Characteristics of Households}

Results of the study reveal that three types of house were identified in the communal district I of Maradi: 1) The houses made of clay bricks, which represent $3.1 \%$ of the sample, are fully built with clay material and are found in old quarters (the largest percentage is found in Soura Bildi); 2) 34.1\% of the houses are semi hard built of clay plastered with cement; and 3) $62.8 \%$ of the houses are built entirely with cement and are mainly found in Zaria area (about 97.7\%).

The age group that has the largest number of heads of household is 31 - 40 years with $32.5 \%$ followed by the class 41 - 50 years (31\%). This distribution reflects a certain young population. The responsibility of the head of household, in $93.8 \%$ of cases, is masculine against $6.2 \%$ held by women.

The current study revealed that a sizeable percentage of number of the respondents, of about $7 \%$ had tertiary education, $24.8 \%$ secondary school education, $20.1 \%$ primary school education, 28.7 koranic education and 19.4 with no formal education.

Among the population of the district, $90 \%$ of heads of household have a profession (farmer or raiser, trader, mechanic technician, driver and employee. The others $10 \%$ with no activity are composed of pensioners and housewives.

\subsection{Wastewater Production}

According to the results of the survey, each household head is responsible of an average of 14 people. The results of the survey reveal that domestic wastewater in the study area is generated from four (4) different sources which are the shower, the laundry, the dishwashing and the income generating activities. Then, the estimation of the volume of domestic waste water produced was made considering the number of 1) individuals per household; 2) the number of showers per day for each individual; and the volume of water used per shower 3), the number of laundry performed by each individual per week 4); the volume of water used per laundry 5); le volume of water used for dishwashing per day 6) and the volume of water used for income generating activities daily 7).

The total volume of wastewater daily produced in the communal district I of Maradi is of about $44.95 \mathrm{~m}^{3}$ by 1393 individuals (Figure 1). The largest parts of this quantity are produced in Soura Bildi and I Zaria neighborhoods with 16.86 and $15.39 \mathrm{~m}^{3}$ respectively.

A descriptive analysis of the wastewater quantities generated, by the households of this district, according to the sources give the results shown in the following Table 1.

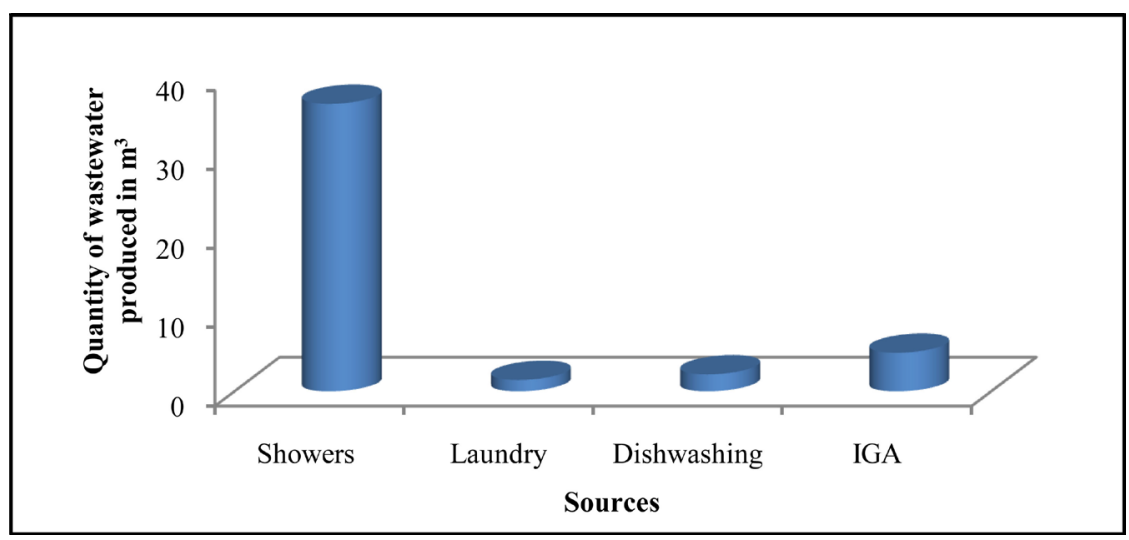

Figure 1. Total volume of wastewater produced in the communal district I of Maradi by production source. 
Table 1. Descriptive statistics of wastewater generated in the communal district I of Maradi per production source.

\begin{tabular}{cccccc}
\hline Sources & $\mathrm{N}$ & Minimum (in liter) & Maximum (in liter) & Mean & Std. Deviation \\
\hline Shower & 129 & 25.00 & 1050.00 & 282.6550 & 238.96194 \\
Laundry & 129 & 1.43 & 60.00 & 11.1074 & 9.66967 \\
Dishwashing & 129 & 10.00 & 40.00 & 16.6667 & 6.41450 \\
Income generating activities (IGA) & 129 & .00 & 60.00 & 37.9070 & 13.44401 \\
Valid N (listwise) & 129 & & & \\
\hline
\end{tabular}

It appears that the wastewater quantity varies depending on the source. The average quantity produced by source and per household are as follow: 282.65; 11.10; 16.66 and 37.90 liters respectively generated by shower, laundry, dishwashing and income generating activities.

\subsection{Wastewater Management Practices at Household Level}

Wastewater sanitation structures in the study area can be divided into two categories: individual sanitation facilities (latrines and septic tanks) and collective sewerage structures (drainage system of rainwater). In this study, improved latrine means a defecation pit covered with a concrete slab.

In the study area, personal sanitation is the only sanitation mode used because public one is nonexistent. About $14 \%$ of surveyed households use modern toilet and have an internal shower and $46 \%$ have the system with septic tank.

It also emerged from this study that domestic wastewater is collected by individual facilities (latrines, cesspools, septic tanks). They are the only ones mainly used in the study area (3.9\% and 79.9\% respectively traditional and improved latrines). Only about $16.2 \%$ of surveyed households use modern sanitation facilities (Figure 2). This confirms that the majority of people in the communal district I of Maradi do not use improved sanitation facilities.

All households surveyed in the study area are aware of the existence of wastewater drain services. However, only $21.7 \%$ of households use their services. As for septic tanks, $75.1 \%$ of households empty them manually.

All the households surveyed in the study area are aware of the existence of the wastewater drain services. However, only $21.7 \%$ of households use their services. Concerning the septic tanks, $75.1 \%$ of households emptied them manually.

Manual pit emptying means that a hole is made next to the septic tank and its content is returned in it and buried. Another method of emptying pits is to pour its contents into the street during the rains to be evacuated by runoff. Among the $78.3 \%$ of households that do not use the wastewater drain services, $60.3 \%$ do not do it because of its high cost, and $39.7 \%$ believe that the drain is usually poorly done or incomplete.

Regarding the wastewater from the laundry, dishwashing and income generating activities, they are removed very often in the street or in the gutters (Figure 3). In some households, these waters are discharged even in the courtyard of the house.

Household participation to a sanitation project of wastewater management is a necessity in the context of the sanitation conditions identified in this study. The households interviewed are aware of the magnitude of the consequences on their environment, health and quality of life, due to the mismanagement of the sanitation sector of wastewater. However, 69.8\% of households surveyed do adhere to a sanitation project if the services are free. Although the population is aware of its responsibility in the unhealthiness in the study area, only $20.9 \%$ of households are willing to invest in a project to clean up their environment and 9.3\% do not want it at all.

In the study area, the living environment is continually deteriorated by wastewater. Direct observations reveal that the soil is polluted, the immediate environment of dwellings is deteriorated by septic tanks overflow and wastewater discharge in the streets. The streets are unhealthy and unsightly. The front of $68 \%$ of the surveyed households' habitat is invaded by sewage and the air is polluted by the release of noxious odors. The highest percentages of houses whose fronts are unhealthy are found in the districts of Zaria, Soura Bildi and Nouveau carré with respectively $92.8 \%, 76.9 \%$ and $56 \%$, with the presence of sewage.

\subsection{Wastewater Management Practices at Communal Level}

It is apparent from field observation and interviews with municipal services, responsible for sanitation in the 


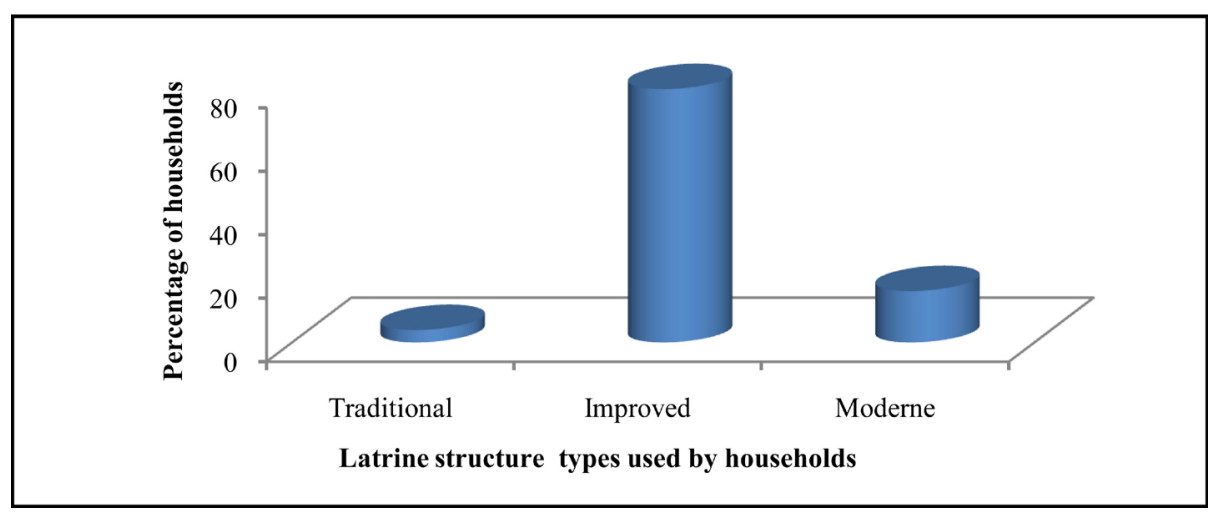

Figure 2. Latrine structures’ types used in the communal district I of Maradi.

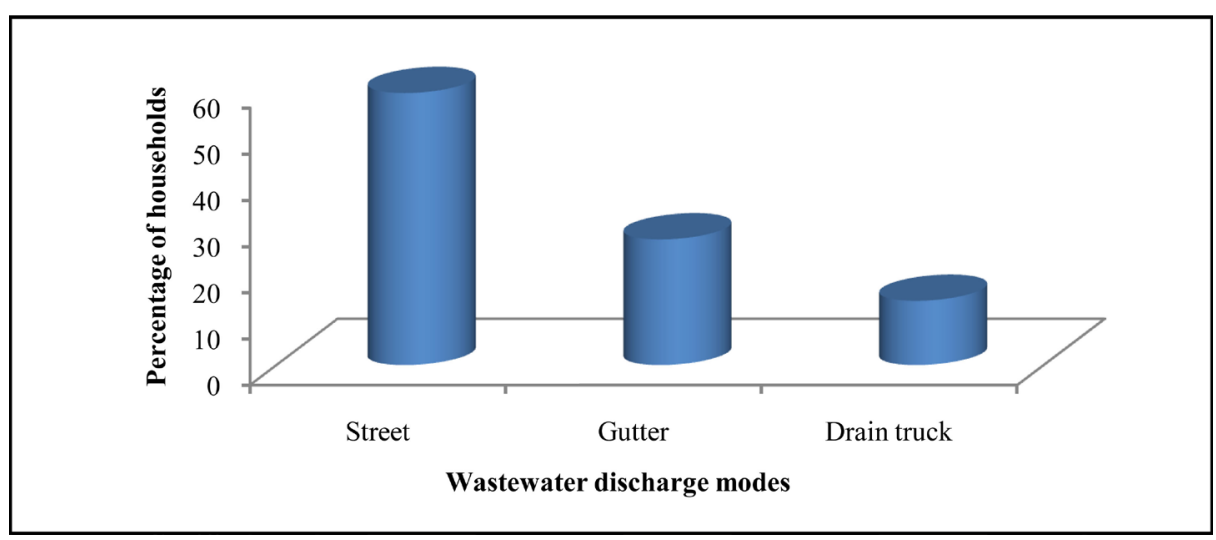

Figure 3. Wastewater disposal modes used in the communal district I of Maradi.

district, that there is no sewage collection network. The sewage system does not exist in the study area. Each inhabitant manages its wastewater at will. Analysis of the results shows that it is individual sanitation that is used in the study area through latrines, cesspools and septic tanks. These structures are often characterized by deficiencies in their design, realization and maintenance.

In addition, the population most often uses the street as a means of wastewater, and even excreta, disposal. Indeed, $75.1 \%$ of surveyed households empty their tanks or cesspools manually and discharge the waste directly into the street or in a hole dug next, against $24.9 \%$ who use services drain trucks. Wastewater from the laundry is also systematically discharged in the street or in the gutters made for the rainwater evacuation. The result is an almost permanent presence of sewage in the streets as illustrated by the rate of $62.1 \%$ of the households having permanent water in front of their houses.

The consequent pollution due to the discharge of wastewater in the streets and their stagnation is important in the study area. About 34.9\% of the surveyed households complain about the proliferation of some diseases' vectors like mosquitoes, flies, cockroaches etc., $26.3 \%$ of the release of odors and $38.8 \%$ fear the disease risks related to the presence of germs and other pathogens in the wastewater.

Also results of the surveys reveal that there is no wastewater management system in the city of Maradi nor in the municipal district Maradi I. Indeed, at the city level, there is no specialized unit responsible for wastewater treatment. Also, there is no sewage system for the collection of these waters, and none other alternative is offered to the population for sanitation. There is also no system for evacuating wastewater. However, this service is partly provided by only two private sewage trucks for all the town of Maradi. Also, these drain services are not subjected to any control by the municipality. There is no wastewater treatment plant, the sewage is discharged in nature without any treatment, any security measures nor monitoring. These operations are not regulated and are made in disregard of the elementary rules of hygiene, health and respect for the environment.

A correlative study was conducted to highlight and analyze any possible links between education level and sewage management type, pits or cesspools emptying practice, the membership in a sanitation project of wastewater. 
Table 2. Correlation between education level and 1) wastewater production, 2) wastewater management modes and 3) practices in the communal district I of Maradi.

\begin{tabular}{cccccc}
\hline & $\begin{array}{c}\text { Level of } \\
\text { education }\end{array}$ & $\begin{array}{c}\text { Volume of wastewater } \\
\text { generated per household }\end{array}$ & $\begin{array}{c}\text { Wastewater } \\
\text { management mode }\end{array}$ & $\begin{array}{c}\text { Wastewater } \\
\text { drain practice }\end{array}$ & $\begin{array}{c}\text { Joining a wastewater } \\
\text { sanitation project }\end{array}$ \\
\hline Pearson Correlation & 1 & $-0.278^{* *}$ & $0.256^{* *}$ & $0.237^{* *}$ & -0.069 \\
Sig. (2-tailed) & - & 0.001 & 0.003 & 0.007 & 0.437 \\
N & 129 & 129 & 129 & 129 & 129 \\
\hline
\end{tabular}

NB: ** indicate that the statistical difference is highly significant (Tukey-Kramer Multiple Comparisons Test, $p<5 \%$ ).

The results of the analysis (Table 2) show that the level of education has an influence on the quantity of wastewater produced, on the method of wastewater management practice and on the wastewater disposal (pits or cesspools).

The higher the education level of the household head, the lower the amount of wastewater generated is significant $(r=-0.278 ; p=0.001)$, better the household handle the wastewater $(r=0.256 ; p=0.003)$ and adopt a healthier drain practice $(r=0.237 ; \mathrm{p}=0.007)$.

However, the education level of the household head has no influence on the intention to join a wastewater sanitation project $(r=-0.069 ; \mathrm{p}=0.437)$. This supposes that the population is partly responsible for the unhealthiness in the study area.

\section{Discussion}

Analysis of the results reveals that the amount of waste water produced by the population of the Municipal District I Maradi is important and is generated by several sources. This fact is explained by the population density and the high growth rate of the population. The main sources of domestic wastewater are the shower, laundry, dishwashing and income generating activities.

The results also showed that unhealthiness in the communal District I of Maradi is related to the sanitation system used. Individual and autonomous sanitation system used in the district does not play its role as the sanitation structures are poorly designed, poorly executed and poorly maintained. Failure of many onsite systems is generally not due to inherent flaws in system technology, but rather due to inappropriate siting and design issues or their operation and management are poorly executed [7]. According to a study report on sanitation access, conducted in five African countries (Niger, Sierra Leone, Ghana, Uganda and Rwanda) the Niger's population increased by 7.7 million inhabitants between 1990 and 2010 while only one million of people have access to sanitation during the same period [8]. The report also points out that nearly $91 \%$ of Niger's population currently lack access to proper toilets. This could be explained by the low-income population because the construction of a latrine - even traditional ones - requires money to buy cement and rebar for the slab, not counting the labor of work. According to Nassartbaye (2011) [9], in Gamkalé neighborhood in Niamey, more than 23\% of the population have no latrine and live in a very unhealthy environment.

The results of our study also established correlations between wastewater management practices, individual behaviors and unhealthiness in the study area. It is clear from these results that the population is partly responsible for the unhealthy environment in the municipal district Maradi I. The study of Younsa (2011) [10] in the "Pays-bas" neighborhood (Niamey), revealed that 52.5\% of households discharge their wastewater in the street. Populations have adapted to this system despite all the health and environmental risks to which they are exposed. This unhealthiness environment is common to all the cities of Niger. The impacts associated with onsite wastewater treatment systems has come to the fore in recent years in order to protect public health and the environment from the consequences of poorly performing systems, in particular septic tanks [11] [12].

The study has also highlighted the responsibility of municipalities in the sanitation conditions in the study area. Indeed, there is no wastewater management system, nor a service in charge of wastewater treatment and no control is done in this field of discharge. However, it is well known that the municipal authorities have the responsibility for waste management and wastewater treatment. Winkler (2005) [13] has shown that the sanitation sector is not a concern of municipal authorities. Yet in the context of adoption of innovative practice, sanitation could prove to be an effective tool in the fight against poverty. Under the "Projet d'Assainissement Productif" (Productive Sanitation Project) in Aguié (Maradi), it has been estimated that the annual quantity of fertilizer 
from sanitation sector produced by a family of nine people correspond to a bag of $50 \mathrm{~kg}$ of urea and another of NPK (15:15:15) [14]. The value of this fertilizer can reach 30 to 40,000 FCFA on the local market. It was estimated for the entire population of Niger in 2009, an annual value of about 60 billion FCFA in fertilizers present in the human excreta, the majority is found in the urine.

The correlation study between the different parameters showed that the higher the education level of the household head, the more households adopts healthier practices for wastewater management. This could be explained by the fact that when we are better informed (through mass media), we paid more attention to what may cause health problems to the family. This result is in line with the findings of works done by Adeyemo and Gboyesola (2013) [15] and Adogu et al. (2015) [16] on knowledge, attitude, and practices on waste management of people living respectively in the university area of Ogbomoso and Owerri Municipality in Nigeria, which indicated that the respondents were knowledgeable in waste management

However, the study also revealed that the level of education has no influence on adherence to a wastewater sanitation project. Malpractice and recklessness of the population could explain this behavior. Indeed, the population of Maradi does not have the habit of the daily cleaning of the front of houses. However, according to Adogu et al. (2015) [16], strict adherence to appropriate waste management practices in any community will insulate the inhabitants from detrimental and hazardous environmental conditions and improve the living standard of the people.

It seems clear that the municipal district I of Maradi does not have a wastewater management system. The sanitation system used through septic tanks, cesspools and latrines does not guarantee the safety of the living conditions of the populations. Nicosia et al. (2001) [17] found that failing septic systems are the most frequently reported cause of groundwater contamination. Also, Carroll et al. (2006) [18] reported that approximately 50\% of waterborne disease outbreaks in the USA were a result of consumption of contaminated groundwater, with septic tanks reported as the most frequent cause of contamination. Populations share the responsibility for the environmental degradation state with municipal authorities. Wastewater management seems not to be a major concern to the municipal authoriyies, probably because of lack of human, financial and material resources. However, Adogu et al. (2015) [16] consider that proper waste disposal management is essential to sustain healthy living conditions in any environment. However, it is well known that municipal wastewater can be an important water resource but its use must be carefully planned and regulated to prevent adverse health effects [19].

In view of the results of this study, we could say that unhealthy state of the study area is also similar in the other two municipal districts of the city of Maradi. The findings should be the same concerning the living environment conditions.

\section{Conclusions}

Unsanitary conditions, in which people live in communal district I Maradi of Maradi, constitute a major problem for the local authorities and the population itself.

The results of this study, conducted in this District, show that this population produces significant quantities of domestic wastewater from showers, laundry, dishwashing and income generating activities. However, there is no sanitation system at the administrative entity level, and no service is set up to handle the wastewater management. This demonstrates a certain lack of involvement of local authorities in this area.

Also, it is demonstrated that the type of sanitation used remains the main cause of unhealthiness in the area, but it is also worth noting that the population is partly responsible for this situation, because of the adoption of malpractice management of wastewater. It is routinely discharged in the street gutter if they exist or even in the courtyard of the concession.

Large numbers of the population are aware of the consequences of the non wastewater management. However, membership household for a possible project of wastewater treatment in the study area did not find a fairly favorable response and participatory. This reflects a kind of wait-and resignation of the population to face its responsibilities in maintaining their lifestyle in a healthy state. As rightly has said Konaté (2012) [20], sanitation should not be regarded as a burden to be borne by the local authorities and population; it is a sine qua non condition for sustainable development. Therefore, efforts must be provided at all levels to solve the problem of hygiene and sanitation in the communal District I of Maradi and even in the entire town of Maradi where the urbanization rate and increase of the population continue to rise. 


\section{References}

[1] Emigilati, M.A., Ishiaku I., Usman, B.Y., Kuta, G.I. and Dangana, K. (2015) Assessment of Effluents Discharged from Textiles Industries in Selected Villages in Kaduna State, Nigeria. African Journal of Environmental Science and Technology, 9, 385-389.

[2] Lacina, C., Diomandé, D., Coulibaly, A. and Gourène G. (2004) Utilisation des ressources en eaux, assainissement et risques sanitaires dans les quartiers précaires de la commune de Port-Bouët (Abidjan; Côte d’Ivoire). Vertigo, 5, Issue 3. http://vertigo.revues.org/3299

[3] Diallo, B.D. (2012) Cours de Gestion écologique des déchets ménagers. Master en Agriculture Durable. Service des Etudes Avancées, Institut Supérieur Agronomique et Vétérinaire de Faranah, Guinée, 104 p.

[4] Institut National de la Statistique (2012) Recensement Général de la Population et de l’Habitat. INS, Ministère des finances, République du Niger, 10 p. http://www.stat-niger.org/statistique/file/rgph2012.pdf

[5] Visticot, C. and Morin, C. (2005) La réalisation d’une enquête, Pédagogie, Économie et gestion, Académie d’AixMarseille. http://www.ecogesam.ac-aix-marseille.fr/Resped/Commerce/Outils/

[6] Ministère de l'industrie du Canada (2010) Méthodes et pratiques d'enquête. Statistique Canada. http://www.statcan.gc.ca/pub/12-587-x/12-587-x2003001-fra.pdf

[7] Otis, R.J. and Anderson, D.J. (1994) Meeting Public Health and Environmental Goals: Performance Standards for Onsite Wastewater Treatment Systems. Proceedings of the Seventh National Symposium on Individual and Small Community Sewage Systems, Atlanta, Georgia, 11-13 December 1994, 1-10.

[8] Ousseini, I. (2013) NIGER: Très peu de gens ont accès à l’assainissement. Inter Press Service News Agency. http://ipsinternational.org/fr/_note.asp?idnews=7474

[9] Nassartbaye, N. (2011) Accès à l'eau potable et à l'assainissement; quels enjeux pour la santé dans les quartiers précaires? Etude appliquée au quartier Gamkallé de la commune IV de Niamey au Niger. MSc Dissertation, Abdou Moumouni University of Niamey, Niamey.

[10] Younsa, H.H. (2011) L'accès à l'eau potable et à l'assainissement dans les quartiers précaires de Niamey: Cas de Pays-bas (commune IV). MSc Dissertation, Abdou Moumouni University of Niamey, Niamey

[11] Geary, P.M. and Whitehead, J.H. (2001) Groundwater Contamination from On-site Domestic Wastewater Management Systems in a Coastal Catchment. In: Proceedings of the Ninth National Symposium on Individual and Small Community Sewage Systems, American Society of Agricultural Engineers, Fort Worth, Texas, 11-14 March 2001, 479-487.

[12] Lipp, E.K., Farrah, S.A. and Rose, B. (2001) Assessment and Impact of Microbial Fecal Pollution and Human Enteric Pathogens in a Coastal Community. Marine Pollution Bulletin, 42, 286-293. http://dx.doi.org/10.1016/S0025-326X(00)00152-1

[13] Winkler, S. (2005) Les expériences du CREPA dans la promotion de l'assainissement autonome en Afrique de l'Ouest: Etat des lieux, analyse et perspectives. Mémoire de recherche, Ecole Polytechnique Fédérale de Lausanne, cycle postgrade environnement: Sciences, ingénierie \& management.

[14] Linus, D., Kailou, H. and Hadidjatou, I. (2009) L’assainissement productif à Aguié, Niger, Le secteur agricole prend le volant, Symposium Régional sur l'Assainissement et l'Hygiène en Afrique de l'Ouest, Accra, Ghana, 3-5 November 2009.

[15] Adeyemo, F.O. and Gboyesola, G.O. (2013) Knowledge, Attitude and Practices on Waste Management of People Living in the University Area of Ogbomoso, Nigeria. International Journal of Environment Ecology, Family and Urban Studies, 3, 51-56.

[16] Adogu, P.O.U., Uwakwe, K.A., Egenti, N.B., Okwuoha, A.P. and Nkwocha, I.B. (2015) Assessment of Waste Management Practices among Residents of Owerri Municipal Imo State Nigeria. Journal of Environmental Protection, 6, 446-456. http://dx.doi.org/10.4236/jep.2015.65043

[17] Nicosia, L.A., Rose, J.B. and Stewart, M.T. (2001) A Field Study of Virus Removal in Septic Tank Drain Fields. Journal of Environmental Quality, 30, 1933-1939. http://dx.doi.org/10.2134/jeq2001.1933

[18] Carroll, S., Goonetilleke, A., Thomas, E., Hargreaves, M., Frost, R. and Dawes, L. (2006) Integrated Risk Framework for Onsite Wastewater Treatment Systems. Environmental Management, 38, 286-303. http://dx.doi.org/10.1007/s00267-005-0280-5

[19] Bouwer, H. (2000) Integrated Water Management: Emerging Issues and Challenges. Agricultural Water Management, 45, 217-228. http://dx.doi.org/10.1016/S0378-3774(00)00092-5

[20] Konaté, S. (2012) Gestion des eaux usées domestiques dans le district de Bamako. Cas de la commune V, MSc Dissertation, University Institute of Territorial Development, Mali. 